\title{
Investigation of Alexithymia, Anxiety and Loneliness State in Bruxism Patients
}

\section{Bruksizmli Hastalarda Aleksitimi, Kaygı ve Yalnızlık Durumunun incelenmesi}

\author{
(D) Esra Talay Çevlik ${ }^{1}$, (D) Göknil Alkan Demetoğlü ${ }^{1}$, (D) Rahşan Çevik Akyıl ${ }^{2}$, (D) Musa Şamil Akyıl ${ }^{1}$ \\ ${ }^{1}$ Aydın Adnan Menderes University Faculty of Dentistry, Department of Prosthodontics, Aydın, Turkey \\ ${ }^{2}$ Aydın Adnan Menderes University Faculty of Nursing, Department of Internal Medicine Nursing, Aydın, Turkey
}

\section{Keywords}

Alexithymia, awake bruxism, sleep bruxism, loneliness, state anxiety, trait anxiety

\section{Anahtar Kelimeler}

Aleksitimi, uyanık bruksizm, uyku bruksizmi, yalnızlık, durumluk kaygı, sürekli kaygı

Received/Geliş Tarihi : 13.05 .2020

Accepted/Kabul Tarihi : 29.07.2020

doi:10.4274/meandros.galenos.2020.85547

Address for Correspondence/Yazışma Adresi: Esra Talay Çevlik MD,

Aydın Adnan Menderes University Faculty of Dentistry, Department of Prosthodontics, Aydın, Turkey

Phone : +90 5425094931

E-mail : esra.talay.cevlik@adu.edu.tr

ORCID ID: orcid.org/0000-0002-8898-6710

(C) Meandros Medical and Dental Journal, Published by Galenos Publishing House.

This is article distributed under the terms of the Creative Commons Attribution NonCommercial 4.0 International Licence (CC BY-NC 4.0).

\begin{abstract}
Objective: Bruxism is a common condition that is described as a diurnal or nocturnal repetitive jaw-muscle movement involving teeth clenching and grinding. This present study aimed to determine the levels of alexithymia, anxiety and loneliness in bruxism patients and to investigate whether associations exist among them.

Materials and Methods: A total of 81 participants (51 women and 30 men) were evaluated. Data were collected through face-to-face interviews with the participants using the Toronto Alexithymia scale-20, The University of California Los Angeles Loneliness scale (UCLA-LS) and State-Trait anxiety inventory (STAI-I and II).

Results: The study revealed that none of the participants was alexithymic. On the other hand, the highest mean score for the UCLA-LS $(54.6 \pm 6.1)$ was found in the 51 years and above age group. The mean STAI-I was highest in the 18-28 years age group (41.1 \pm 9.4 ) and among females $(44 \pm 7.2)$, university graduates $(40.3 \pm 9.2)$ and singles (41 \pm 9.4$)$. The mean STAI-II score was found to be highest in the 40-50 years age group $(48.7 \pm 14.8)$ and among females $(44 \pm 7.2)$, high school graduates $(43.4 \pm 11.1)$ and singles $(42.6 \pm 8.5)$. The distribution of the mean trait anxiety scores was found to be statistically significant with regard to gender $(p<0.05)$.

Conclusion: The results showed that individuals with bruxism who were evaluated within the scope of this study were not alexithymic; however, they had high levels of loneliness. The alexithymia, loneliness and state and trait anxiety scores had significant positive associations with each other.
\end{abstract}

Öz

Amaç: Bruksizm, dişlerin sıkılması ve gıcırdatılmasını içeren gün içerisinde veya gece, tekrarlayan çene-kas hareketi olarak tanımlanan yaygın bir durumdur. $\mathrm{Bu}$ çalışmanın amacı, bruksizm hastalarında aleksitimi, anksiyete ve yalnızlık düzeylerini belirlemek ve aralarındaki ilişkilerin varlığını araştırmaktır.

Gereç ve Yöntemler: Toplamda 81 katılımcı (51 kadın ve 30 erkek) değerlendirilmiştir. Veriler, katılımcılarla Toronto Aleksitimi ölçeği-20, Kaliforniya Los Angeles Üniversitesi Yalnızlık ölçeği (UCLA-LS) ve Durumluk Sürekli Kaygı Envanteri (STAI-I ve II) kullanılarak yüz yüze görüşme tekniği ile elde edilmiştir.

Bulgular: Çalışma, katılımcıların hiçbirinin aleksitimik olmadığını ortaya koymuştur. Öte yandan, UCLA-LS $(54,6 \pm 6,1)$ için en yüksek ortalama puan 51 yaş ve üstü grupta belirlenmiştir. Ortalama STAI-I $18-28$ yaş grubunda $(41,1 \pm 9,4)$, kadınlarda $(44 \pm 7,2)$, 
üniversite mezunlarında $(40,3 \pm 9,2)$ ve bekarlarda $(41 \pm 9,4)$ en yüksektir. Ortalama STAI-II skoru $40-50$ yaş grubunda $(48,7 \pm 14,8)$, kadınlarda $(44 \pm 7,2)$, lise mezunlarında $(43,4 \pm 11,1)$ ve bekarlarda $(42,6 \pm 8,5)$ en yüksek olarak belirlenmiştir. Ortalama sürekli kaygı puanlarının dağılımı cinsiyet açııından istatistiksel olarak anlamlı bulunmuştur $(p<0,05)$.

Sonuç: Sonuçlar, bu çalışma kapsamında değerlendirilen bruksizmi olan bireylerin aleksitimik olmadığını göstermiştir; ancak, yüksek düzeyde yalnızlık vardır. Aleksitimi, yalnızlık, durum ve sürekli kaygı puanları birbirleriyle anlamlı pozitif ilişkilere sahiptir.

\section{Introduction}

\section{Bruxism}

Bruxism is a common condition which is described as a diurnal or nocturnal repetitive jaw-muscle movement involving teeth clenching and grinding. Since the sleep-wake state of the condition is part of this definition, "sleep/wake" definition is preferred instead of "nocturnal/diurnal" (1). The data obtained from adult populations in Paesani's (2) recent systematic review of epidemiologic aspect of bruxism revealed a prevalence of $18.6 \%$ for bruxism, $15.9 \%$ for sleep bruxism, and $23.8 \%$ for awake bruxism. Bruxism is named as primary when no predisposing medical situation has been found to be present, and secondary when it has occurred as a consequence of a medical or psychiatric problem (3). Bruxism may involve grinding with or without static teeth clenching. It is associated with noise in approximately one-third of sleep bruxists (4). Awake bruxism is generally in the form of silent static clenching; grinding at the awake state is usually only as a consequence of administered medications or neurological diseases (5).

Centrally-acting pathophysiological mechanisms have been suggested to contribute to the onset of sleep bruxism $(5,6)$, and numerous psychological factors such as stress and anxiety appear to aggravate sleep bruxism, causing an intricate pattern consisting of merged states (7). The psychosocial theory has argued that stress and personality type might have crucial roles in bruxism; it hypothesizes that stresses caused by daily life increase the severity and frequency of tooth squeezing and grinding (8). However, no specific personality trait was found to be present in patients with bruxism, and the researchers have found different results. Several studies based on personal reports and questionnaires have shown that patients with bruxism were more anxious, aggressive, and hyperactive $(9,10)$.

Among the parafunctional activities of the stomatognathic system, bruxism is considered the most detrimental activity, eventually leading to tooth wear, periodontal disorders, and articular and/ or muscular injuries (11). In the clinical examination of the oral cavity, signs of bruxism including tooth wear, tongue and cheek indentations, hypertrophy of masticatory muscles, jaw muscle tenderness or pain on digital palpation and morning headache complaints can be observed $(6,12,13)$. It was reported that bruxism, particularly the type occurring during sleep has a significant effect on the etiology of temporomandibular disorders (TMD), adding up to various psychological factors effective on its onset and/or maintenance $(14,15)$.

Sifneos (16) defined the term alexithymia to express a deficiency regarding differentiation of the emotional and somatic states. During the next decade, it was theoretically refined and evolved to a paradigm regarding identification of the effects of feelings and identity on somatic disorders (17). Loneliness is an unpleasant emotional state experienced as a consequence of discrepancies among the social affiliations of the individual and the social relationships that the individual desires to maintain (18). Along with the rapidly growing population and developing technology, alexithymia and loneliness tend to increase in parallel with the widespread use of computers and the internet (19).

Previous studies have neither investigated the presence of alexithymia state in individuals with bruxism nor assessed the associations of alexithymia, anxiety, and loneliness state in individuals with bruxism. The present study aimed to investigate the status of the individuals with bruxism regarding the presence of alexithymia, anxiety, and loneliness, and to investigate the associations among them.

\section{Materials and Methods}

\section{Ethics}

The research protocol gained approval from the Ethics Committee of Aydın Adnan Menderes University, Faculty of Dentistry (protocol no: 98318678-020). The study was conducted at Aydın 
Adnan Menderes University, Faculty of Dentistry between June 2018 and November 2018. The participants of the study were unpaid volunteers. All participants provided written consent to the approved protocol as they were free to decline their participation. The personal data of the participants were kept confidential.

\section{Participants}

In this period, eighty-one participants (51 women and 30 men) who had been referred to the department of prosthodontics were evaluated. The diagnosis of bruxism was made in two steps: the first step was obtaining the patient report and clinical interview results, and the second step was a clinical and intraoral examination. The primary exclusion criteria for participants were the presence of accident-related TMD, preoperative treatments, and chronic pain disorders other than those caused by TMD. The following demographic characteristics of the participants were recorded and taken into consideration: age, gender, educational level, marital status.

\section{The Patient Record and Clinical Interview}

The appropriate questions were presented in Table $1(20,21)$. Regarding the patient records and clinical interviews, questions were replied as "yes" or "no" by the participants. If the response was "yes", for a more detailed description of the habit, the patient was queried as "how many times per week".

If the questions were replied as "yes" and teeth grinding habit was determined as at least three times a week, the results were suggested to be supportive for the diagnosis of bruxism. In addition, on intraoral examination, the individuals who were found to have at least one of the findings shown in Table 1 were considered to have bruxism.

\section{Questionnaires}

Data were collected from individuals who were considered to have bruxism by the face-toface interviewing method asking the following questionnaires: The Toronto Alexithymia scale (TAS20), the University of California Los Angeles Loneliness scale (UCLA-LS), the State-Trait Anxiety inventory (STAI) forms together with the data sheet including patients' age, gender, educational level, and marital status.

\section{Toronto Alexithymia Scale}

Since the most commonly used and validated self-report measurement of alexithymia is currently the TAS-20 (22), the participants were requested to reply to the TAS-20 questionnaire in order to evaluate alexithymia. The TAS-20 questionnaire consisted of 20 questions, including 7 questions regarding difficulty in interpreting feelings, 5 questions regarding difficulty in describing feelings, and 8 questions for externally oriented thinking. The replies were scored between 1 and 5 according to the 5 -point Likert scale. The Turkish version of the TAS was validated by Sayar et al. (23) in 2001. According to Sayar et al.'s (23) suggestions, people are considered to be alexithymic if the overall score is above 61 . People with a score below or equal to 61 are considered non-alexithymic. High scores suggest high levels of alexithymia.

\section{The University of California Los Angeles} Loneliness Scale

UCLA-LS was established by Russell (24) in order to evaluate the loneliness level in general. It is a 4-point

\begin{tabular}{|c|c|}
\hline \multirow{4}{*}{ Questions to use during history-taking } & Are you aware of grinding your teeth during sleep? \\
\hline & Has anyone told you that you grind your teeth during sleep? \\
\hline & On waking, do you experience pain or stiffness in the jaw muscles? \\
\hline & On waking, do you have your jaws clenched or thrust forward? \\
\hline \multirow{6}{*}{$\begin{array}{l}\text { Factors on clinical examination } \\
\text { suggestive of bruxism }\end{array}$} & Masseteric hypertrophy \\
\hline & Muscle tenderness on palpation \\
\hline & $\begin{array}{l}\text { Wear facets on occlusal surfaces either within the normal envelope of movement of at } \\
\text { eccentric jaw positions: termed: "bruxofacets" }\end{array}$ \\
\hline & Shiny spots on restorations \\
\hline & Restoration or tooth fracture \\
\hline & Tongue scalloping and ridging on the cheek mucosa ("linea alba") \\
\hline
\end{tabular}


Likert type scale comprising of 20 items (10 positives and 10 negatives). Participants were asked to reply to 20 items, and their replies were scored between 1 "never" and 4 "often" according to the scale. Scale scores range between 20 and 80 , and a lower score was indicative of a lower loneliness level (24). The Turkish version of the UCLA-LS was validated by Demir (25) in 1989.

\section{State-Trait Anxiety Inventory}

STAI was established by Spielberger et al. (26) for interpretation of the severity of anxiety symptoms and discovering the presence of a generalized tendency to be anxious through self-reporting. The Turkish version of the STAI was validated by Oner and Le Compte (27) in 1983.

Two subscales take place within this scoring system. The State Anxiety (S-Anxiety) scale assesses the present anxiety state, querying how participants feel "at this moment," using items for evaluating subjective emotions. The Trait Anxiety (T-Anxiety) scale assesses the relatively substantial aspects of "anxiety proneness," involving the calmness, confidence, and security states. The STAI involves a total of 40 items, with 20 items allocated to each subgroup (28). The replies regarding the S-Anxiety scale assess the intensity of currently present feelings: 1 ) not at all, 2) somewhat, 3 ) moderately so, and 4) very much so. The replies regarding the T-Anxiety scale interpret the frequency of feelings "on the whole": 1) almost never, 2) sometimes, 3) often, and 4) almost always. The subtest total scores are calculated by the addition of the item scores. STAI scores vary in a range between 20 to 80 for each subtest, a lower score indicating a lower anxiety level. The cut-off point of 39-40 was suggested in the study conducted by Knight et al. (29) to identify the clinically important symptoms regarding the S-Anxiety scale. Nevertheless, a higher cut-off value of 54-55 was recommended for older adults in other studies (30). The revised manual for the STAI involves the normative values for adults, college students, and psychiatric samples (31).

\section{Limitations of Our Study}

The limitation of our study was the selection of the sample group by the non-probabilistic sampling method. Therefore, study results could only be generalized to the selected sample group.

\section{Statistical Analysis}

All analyses were carried out using SPSS software. The descriptive statistics and frequency values were obtained to characterize the study sample. ANOVA and the t-test were used for comparison of the severity regarding the qualitative nominal variables among the groups. Pearson's correlation test was performed to assess the relationships among variables. The significance level was controlled at the level of 0.05 .

\section{Results}

The total sample consisted of 81 participants (63\% female) in the study. The mean age was 25.7 years in the total sample. Most of the participants had graduated from a university $(91.4 \%)$, were single (84\%) and female (63\%) (Table 2).

The distributions of the demographic features of the participants according to their TAS-20, UCLA-LS, and STAI scores were shown in Table 3. According to the results of our study, the participants' score was below 61 . In this study, none of the participants was classified as alexithymic. Meanwhile, regarding the UCLA-LS scale, in which the mean score of 49 and above suggests "high loneliness," such a score was determined in all demographic characteristics. The highest score was obtained from the group aged

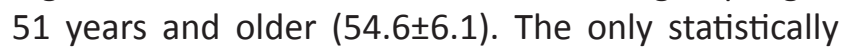
significant difference was found to be present between the genders regarding the mean trait anxiety score $(p<0.05)$.

The results of the correlation analysis revealed that there was a significant positive correlation between

Table 2. Demographic characteristics of the participants

\begin{tabular}{|l|l|l|}
\hline \multicolumn{2}{|l|}{ Age } & \multicolumn{2}{l|}{$\%$} \\
\hline $18-28$ & 67 & 82.7 \\
\hline $29-39$ & 5 & 6.2 \\
\hline $40-50$ & 4 & 4.9 \\
\hline $51+$ & 5 & 6.2 \\
\hline Gender & 5 & \multicolumn{2}{l|}{} \\
\hline Female & \multicolumn{2}{l|}{} \\
\hline Male & 51 & 63.0 \\
\hline Educational level & 30 & 37.0 \\
\hline High school & \multicolumn{2}{l|}{} \\
\hline University (Academy, faculty) & 74 & 8.6 \\
\hline Marital status & 7 & 91.4 \\
\hline Married & \multicolumn{2}{l|}{} \\
\hline Single & 13 & 16.0 \\
\hline
\end{tabular}


alexithymia and state anxiety, and trait anxiety scales in patients with bruxism $(p<0.01)$. Similarly, there was a significant positive correlation between the state anxiety and trait anxiety scores $(p<0.01)$ (Table 4$)$.

\section{Discussion}

The dental profession is currently interested with the etiology of bruxism, which has been hotly debated for years. The inventory of probable sources of bruxism involves psychological, physical, mechanical, genetic, and even microbiological factors; emotional stress, anxiety, sleep disturbances, dental malocclusion, eccentric tooth contacts, genetic factors, medications, alcohol consumption, breathing disorders, allergies, mental disorders, and even pinworms have been suggested as probable factors leading to bruxism (2).

It has been well-identified that bruxism is related to individuals' emotional states. In this study, our aim was to determine the alexithymia, loneliness, S-Anxiety, and T-Anxiety scores in individuals with bruxism and to determine potential correlations among them. When the medical literature was reviewed, no report

Table 3. Distributions of the demographic features of the participants according to their TAS-20, UCLA-LS, and STAI scores $(n=81)$

\begin{tabular}{|c|c|c|c|c|c|c|c|c|}
\hline \multirow[b]{2}{*}{ Age } & \multicolumn{2}{|l|}{ TAS-20 } & \multicolumn{2}{|c|}{ UCLA-LS } & \multicolumn{2}{|c|}{ STAI-TX I } & \multicolumn{2}{|c|}{ STAI-TX II } \\
\hline & Mean & SD & Mean & SD & Mean & SD & Mean & SD \\
\hline $18-28$ & 54.8 & 9.6 & 49.5 & 5.2 & 41.1 & 9.4 & 42.3 & 8.0 \\
\hline 29-39 & 53.2 & 6.9 & 51.0 & 4.6 & 33.2 & 1.7 & 43.6 & 6.5 \\
\hline $40-50$ & 54.7 & 8.6 & 51.7 & 3.3 & 39.7 & 8.6 & 48.7 & 14.8 \\
\hline $51+$ & 53.4 & 8.8 & 54.6 & 6.1 & 35.0 & 11.2 & 38.2 & 5.6 \\
\hline \multicolumn{9}{|l|}{ Gender } \\
\hline Female & 54.2 & 8.5 & 50.4 & 4.9 & 39.3 & 9.0 & 44.0 & 7.2 \\
\hline Male & 55.2 & 10.3 & 49.3 & 5.7 & 41.5 & 10.0 & 39.7 & 9.2 \\
\hline & & & & & & & $t=2.353$ & $p<0.05$ \\
\hline \multicolumn{9}{|l|}{ Educational level } \\
\hline High school & 55.7 & 12.1 & 49.1 & 3.0 & 38.7 & 11.3 & 43.4 & 11.1 \\
\hline University (academy/faculty) & 54.5 & 9.0 & 50.1 & 5.4 & 40.3 & 9.2 & 42.3 & 8.0 \\
\hline \multicolumn{9}{|l|}{ Marital status } \\
\hline Married & 52.6 & 6.7 & 52.1 & 4.9 & 35.6 & 8.0 & 41.5 & 6.6 \\
\hline Single & 54.9 & 9.6 & 49.6 & 5.2 & 41.0 & 9.4 & 42.6 & 8.5 \\
\hline
\end{tabular}

\begin{tabular}{|l|l|l|l|l|l|}
\hline \multicolumn{2}{|l}{ Table 4. Correlation analysis results for mean scores } \\
\hline
\end{tabular}


related to the associations among the alexithymia, loneliness, S-Anxiety, and T-Anxiety levels in individuals with bruxism was found to be present. The results of our study indicated that there was a statistically significant relationship between the alexithymia, loneliness, S-Anxiety, and T-Anxiety levels of the participants.

There are several ways to assess bruxism activity such as using questionnaires, clinical examination, intra-oral appliance, masticatory muscle electromyographic recording, and polysomnography (PSG). Using questionnaires has been the most widely used method (32). Przystańska et al. (33) used questionnaires in a recently published study to assess psychosocial predictors of bruxism. Detection of tooth wear and performing clinical examination have also been commonly utilized in both research and clinical settings $(32,33)$. Currently, the most definitive and precise method for assessing bruxism activity is considered PSG performed in a sleep laboratory (3437). But due to the high cost and limited availability, the PSG technique is suitable only for small samples (38). We preferred using questionnaires in our study because data related to bruxism have been usually gathered from interviews or questionnaires in epidemiological studies in the literature.

It was stated in a recently published review that awake clenching might be related to various psychosocial factors and psychopathological symptoms; however, reports from sleep laboratory studies related to the etiology and characteristics of bruxism did not support the association of psychosocial disorders and bruxism diagnosed with PSG (39). The study conducted by Fernandes et al. (40) reported that patients suffering from a painful TMD had an elevated risk for moderate to severe depression; they added that this risk was even more elevated when the painful TMD was accompanied with sleep bruxism. The main limitation of this study was the fact that PSG-the gold standard-method was not used.

The study conducted by Przystańska et al. (33) reported that most of the bruxers are not alexithymic patients, but all of them revealed a high or average level of stress. In our study, none of the participants were classified as alexithymic, but high loneliness score was detected in all of them. These results may be related to the different distributions of the demographic characteristics of the participants.

It was reported that patients with TMD have little appreciation of their inner states and affections (41). Additionally, patients who have chronic pain due to disorders different than TMD generally present with higher levels of alexithymia when compared to controls $(42,43)$. It was reported that alexithymia and acute pain have a positive relationship $(44,45)$; however, this finding was not supported by many other studies (42-46).

Within the limitations of this study, it was shown that there was a statistically significant positive relationship among the loneliness, state anxiety, and trait anxiety scores in participants with bruxism. High loneliness levels were observed in all demographic characteristics, especially in participants aged over 51 years. Gender was a statistically significant factor affecting the scale of trait anxiety. The highest rate of state anxiety levels was observed in university graduate and single men, aged between 18 and 28 years. According to the results of our study, it should be noted that there are significant effects of age, gender, educational level, and marital status.

\section{Conclusion}

As a conclusion, further studies are needed to determine the potential correlations among psychological conditions in bruxism patients. Moreover, it is suggested that clinicians should consider psychological conditions such as alexithymia, loneliness, state anxiety, and trait anxiety in individuals who are diagnosed with bruxism.

\section{Ethics}

Ethics Committee Approval: The research protocol gained approval from the Ethics Committee of Aydın Adnan Menderes University, Faculty of Dentistry (protocol no: 98318678-020).

Informed Consent: All participants provided written consent to the approved protocol as they were free to decline their participation. The personal data of the participants were kept confidential.

\section{Authorship Contributions}

Concept: E.T.Ç., G.A.D., R.Ç.A., M.Ş.A., Design: E.T.Ç., G.A.D., R.Ç.A., M.Ş.A., Supervision: E.T.Ç., G.A.D., R.Ç.A., M.Ş.A., Fundings: E.T.Ç., G.A.D., R.Ç.A., M.Ş.A., Data Collection or Processing: G.A.D., E.T.Ç., 
Analysis or Interpretation: E.T.Ç., G.A.D., R.Ç.A., M.Ş.A., Literature Search: E.T.Ç., G.A.D., R.Ç.A., M.Ş.A., Critical Review: E.T.Ç., G.A.D., R.Ç.A., M.Ş.A., Writing: E.T.Ç.

Conflict of Interest: No conflict of interest was declared by the authors.

Financial Disclosure: The authors declared that this study received no financial support.

\section{References}

1. Lobbezoo F, Ahlberg J, Glaros AG, Kato T, Koyano K, Lavigne GJ, et al. Bruxism defined and graded: an international consensus. J Oral Rehabil 2013; 40: 2-4.

2. Paesani DA. Introduction to bruxism. In: Paesani DA, editors. Bruxism theory and practice. Chicago; Quintessence Publishing Co, 2010: 3-19.

3. Needham R, Davies SJ. Use of the Grindcare ${ }^{\circledR}$ device in the management of nocturnal bruxism: a pilot study. Br Dent J 2013; 215: E1.

4. Lavigne GJ, Rompre PH, Poirier G, Huard H, Kato T, Montplaisir JY. Rhythmic masticatory muscle activity during sleep in humans. J Dent Res 2001; 80: 443-8.

5. Lavigne GJ, Khoury S, Abe S, Yamaguchi T, Raphael K. Bruxism physiology and pathology: an overview for clinicians. J Oral Rehabil 2008; 35: 476-94.

6. Carra MC, Huynh N, Lavigne GJ. Sleep bruxism: a comprehensive overview for the dental clinician interested in sleep medicine. Dent Clin North Am 2012; 56: 387-413.

7. Khoury S, Carra MC, Huynh N, Montplaisir J, Lavigne GJ. Sleep Bruxism-Tooth Grinding Prevalence, Characteristics and Familial Aggregation: A Large Cross-Sectional Survey and Polysomnographic Validation. Sleep 2016; 39: 2049-56.

8. Ahlberg J, Savolainen A, Rantala M, Lindholm H, Kononen M. Reported bruxism and biopsychosocial symptoms: a longitudinal study. Community Dent Oral Epidemiol 2004; 32: 307-11.

9. Kampe T, Tagdae T, Bader G, Edman G, Karlsson S. Reported symptoms and clinical findings in a group of subjects with longstanding bruxing behaviour. J Oral Rehabil 1997; 24: 581-7.

10. Fischer WF, O'Toole ET. Personality characteristics of chronic bruxers. Behav Med 1993;19:82-6.

11. Okeson JP. American Academy of Orofacial Pain. In: Okeson JP, editors, Orofacial pain: Guidelines for Assessment, Diagnosis, and Management. Chicago: Quintessence Publishing Co, 1996.

12. Lavigne G, Manzini C, Huynh NT. Sleep bruxism. In: Kryger MH, Roth T, Dement WC, editors. Principles and Practice of Sleep Medicine. St Louis, MO: Elsevier Saunders, 2011: 1129-39.

13. Koyano K, Tsukiyama Y, Ichiki R, Kuwata T. Assessment of bruxism in the clinic. J Oral Rehabil 2008; 35: 495-508.

14. Israel HA, Diamond B, Saed-Nejad F. Ratcliffe A. The relationship between parafunctional masticatory activity and arthroscopically diagnosed temporomandibular joint pathology. J Oral Maxillofac Surg 1999; 57: 1034-9.

15. McNeill C. Management of temporomandibular disorders: concepts and controversies. J Prosthet Dent. 1997; 77: 510-22.
16. Sifneos PE. The prevalence of 'alexithymic' characteristics in psychosomatic patients. Psychother Psychosom 1973; 22: 25562.

17. Taylor GJ, Bagby RM, Parker JDA. The alexithymia construct: a potential paradigm for psychosomatic medicine. Psychosomatics 1991; 32: 153-64.

18. Jones WH, Hobbs SA, Hockenbury D. Loneliness and social skill deficits. J Pers Soc Psychol 1982; 42: 682-9.

19. Kocak R. The effect of emotional expression training program on alexithymia and loneliness levels of university students. Turkish Psychological Counseling and Guidance Journal 2005; 3: 29-43.

20. Paesani DA, Lobbezoo F, Gelos C, Guarda-Nardini L, Ahlberg J, Manfredini D. Correlation between self-reported and clinically based diagnoses of bruxism in temporomandibular disorders patients. J Oral Rehabil 2013; 40: 803-9.

21. American Academy of Sleep Medicine, editors. The International Classification of Sleep Disorders: diagnostic and coding manual, 2nd ed. Westchester, Illinois, USA, American Academy of Sleep Medicine, 2005.

22. Bressi C, Taylor G, Parker J, Bressi S, Brambilla V, Aguglia E, et al. Cross validation of the factor structure of the 20-item Toronto Alexithymia scale: An Italian multicenter study. J Psychosom Res 1996; 41: 551-9.

23. Sayar K, Gulec H, Ak I. Validity and Reliability of 20-item Toronto Alexithymia Scale. 37th National Congress of Psychiatry (2-6 October 2001, Istanbul, Turkey). İstanbul: Complete Text Book; 2001: 130.

24. Russell DW. UCLA Loneliness Scale (Version 3): Reliability, validity, and factor structure. J Pers Asses 1996; 66: 20-40.

25. Demir A. Validity and reliability of the UCLA loneliness scale. Turkish Journal of Psychology 1989; 7: 14-8.

26. Spielberger CD, Gorsuch RL, Lushene RE. STAI manual for the State-Trait Anxiety Inventory ("self-evaluation questionnaire"). Alto P, editor. CA: Consulting Psychologists Press; 1970.

27. Oner N, Le Compte WA. Handbook of Discontinuity/Trait Anxiety Inventory. 2nd ed. İstanbul: Bogazici University Press; 1998.

28. Kaipper MB, Chachamovich E, Hidalgo MP, Torres IL, Caumo W. Evaluation of the structure of Brazilian State-Trait Anxiety Inventory using a Rasch psychometric approach. J Psychosom Res 2010; 68: 223-33.

29. Knight RG, Waal-Manning HJ, Spears GF. Some norms and reliability data for the State-Trait Anxiety Inventory and the Zung Self-Rating Depression scale. Br J Clin Psychol 1983; 22: 245-9.

30. Kvaal K, Ulstein I, Nordhus IH, Engedal K. The Spielberger StateTrait Anxiety Inventory (STAI): the state scale in detecting mental disorders in geriatric patients. Int J Geriatr Psychiatry 2005; 20 : 629-34.

31. Spielberger CD. Manual for the State-Trait Anxiety Inventory. In: Alto P, editor. CA: Consulting Psychologists Press; 1983.

32. Nishigawa K, Bando E, Nakano M. Quantitative study of bite force during sleep associated bruxism. J Oral Rehabil 2001; 28: 485-91.

33. Przystańska A, Jasielska A, Ziarko M, Pobudek-Radzikowska M, Maciejewska-SzaniecZ, Prylińska-Czyżewska A, et al. Psychosocial 
predictors of bruxism. Biomed Res Int 2019;2019:2069716. doi: 10.1155/2019/2069716.

34. Velly-Miguel AM, Montplaisir J, Rompre PH, Lund JP, Lavigne GL. Bruxism and other orofacial movements during sleep. J Craniomandib Dis Fac Oral Pain 1992; 6: 71-81.

35. Bowley JF, Stockstill JW, Pierce CJ. Reliability and validity of instrumentation used to record nocturnal clenching and / or grinding. J Orofac Pain 1993; 7: 378-85.

36. Rivera-Morales WC, McCall WD Jr. Reliability of a portable electromyographic unit to measure bruxism. J Prosthet Dent 1995; 73: 184-9.

37. Gallo LM, Lavigne G, Rompre' P, Palla S. Reliability of scoring EMG orofacial events: polysomnography compared with ambulatory recordings. J Sleep Res 1997; 6: 259-63.

38. Treede RD, Jensen TS, Campbell JN, Cruccu G, Dostrovsky JO, Griffin JW, et al. Neuropathic pain: redefinition and a grading system for clinical and research purposes. Neurology 2008; 70: 1630-5.

39. Manfredini D, Lobbezoo F. Role of psychosocial factors in the etiology of bruxism. J Orofac Pain 2009; 23: 153-66.

40. Fernandes G, Franco AL, Siqueira JTT, Goncalves DAG, Camparis CM. Sleep bruxism increases the risk for painful temporomandibular disorder, depression and non-specific physical symptoms. J Oral Rehabil 2012; 39: 538-44.

41. Meldolesi GN, Picardi A, Accivile E, Toraldo di Francia R, Biondi M. Personality and psychopathology in patients with temporomandibular joint pain-dysfunction syndrome. A controlled investigation. Psychother Psychosom 2000; 69: 322-8.

42. Bushnell MC, Villemure $\mathrm{C}$, Strigo I, Duncan GH. Imaging pain in the brain: the role of the cerebral cortex in pain perception and modulation. J Musculoskeletal Pain 2002; 10: 59-72.

43. Lumley MA, Asselin LA, Norman S. Alexithymia in chronic pain patients. Compr Psychiatry 1997; 38: 160-5.

44. Nyklicek I, Vingerhoets AJ. Alexithymia is associated with low tolerance to experimental painful stimulation. Pain 2000; 85: 471-5.

45. Putterman E, Byrne N, Ditto B. Alexithymia and symptom reporting following blood donation. Psychosom Med 2001; 63: 138-9.

46. Lumley MA, Smith JA, Longo DJ. The relationship of alexithymia to pain severity and impairment among patients with chronic myofascial pain: comparisons with self-efficacy, catastrophizing, and depression. J Psychosom Res 2002; 53: 823-30. 